\title{
Impact of human activities on the quality of groundwater at Dobra intake in Jaworzno
}

\author{
Izabela Zimoch ${ }^{1, *}$, and Sylwia Kręcichwost ${ }^{2}$ \\ ${ }^{1}$ Silesian University of Technology, Institute of Water and Wastewater Engineering, 44-100 Gliwice, 18a Konarskiego St., \\ Poland \\ 2 Jaworzno Waterworks Ltd, 43-600 Jaworzno, 34 Św. Wojciecha St, Poland
}

\begin{abstract}
The paper identifies the causes of contamination and analyses changes in the quality of underground water resources at the Dobra intake, which supplies water for a separated group of Jaworzno inhabitants. The analysis takes into consideration such aspects as land conditions and their influence on physicochemical changes of water taken in in relation to the effective legal requirements for potable water. Moreover, an integral part of analysis of potential threats was an assessment of the effect of closed municipal waste disposal site and mining activity on the quantitative and qualitative resources of underground water in the area supplied by the Dobra intake in Jaworzno.
\end{abstract}

\section{Introduction}

Jaworzno is a city shaped by the growth of industry and urbanisation for hundreds of years. Former mining expansion and current widespread liquidation of mines, happening in Jaworzno as well, have influenced the quality and volumes of underground water resources. Strong human impact arising from mining activity conducted in the area of the city led to considerable transformations in the underground water environment. Both surface and underground mining contributed to this. During liquidation of surface mines, and in turn stoppage in functioning of drainage systems, workings became flooded and surface post-exploitation water bodies formed, which are currently used as recreation sites. An example of such human-related changes is the resource area of the Dobra intake in Jaworzno in connection with the formation of the Gródek quarry, which is currently a recreation a scuba-diving centre.

Apart from the mining activity, what had a considerable influence on the quality of underground waters in Jaworzno in terms of human impact, it was also the storage of waste and manner of use of waste disposal sites. The most popular method for disposal of municipal waste in Poland is still their storage, both compliant and not complaint with the currently effective legal requirements. Not long ago, the role of waste disposal sites was played by ground excavations, post-mining excavations, wild open pits, often without any safety measures [1].

Intense development of mining activity and its gradual extinguishing in the 1990s had a profound effect on the quantitative and qualitative dynamics of changes in the quality of underground waters in the resource area of the Dobra intake in Jaworzno. The result of those activities is two identified sources of threat for water quality at the Dobra intake, i.e.: municipal waste disposal site and the Gródek quarry.
The Dobra underground water intake takes water for supplying the inhabitants of specific districts of the city of Jaworzno. This is an underground water intake from Triassic formations with two bored wells D-1 and D-2. The confirmed volume of intake resources is 4.494 $\mathrm{m}^{3} /$ day $\left(187.50 \mathrm{~m}^{3} / \mathrm{h}\right)$. The direct surroundings of the intake are wastelands, farmlands (in the area of the wells) and compact urban development (in the area of the other facilities of the water treatment plant (i.e. WTP). Within $2 \mathrm{~km}$ from the intake, there are the following: to the southeast, the Gródek excavation after dolomite use (currently flooded in part), to the east, urban municipal waste disposal site (located in postdolomite excavations) and to the northwest, a cemetery. $6 \mathrm{~km}$ to the northwest from the area in question there are vast railway areas of the Jaworzno-Szczakowa station. Ca. 5 metre from the D1 well, there is the Łużnik stream, being a right affluent of Kozi Bród. Identification of sources of underground waters contamination and monitoring of changes occurring in their quality is a considerable aspect from the point of view of safe management of water supply systems (WSS) [2-7]. WSS management based on implemented procedures of risk assessment is compliant with the amended Drinking Water Directive - 2015/1787 of 06.10.2015, L 260/6 and Polish standard PN-EN 15975-2 Security of water supply.

\section{Technical characteristics of the Dobra intake}

Wells D-1 and D-2 of the Dobra intake were built in ca. 1917 and were used (mostly well D1) until mid 1987 with constant efficiency of over $1.000 \mathrm{~m}^{3} /$ day (over 42 $\mathrm{m}^{3} / \mathrm{h}$ ), with the determined depression of ca. $3 \mathrm{~m}[8]$.

In the area of the intake, the insulation properties of ground were heavily disturbed during surface 
exploitation of raw rock materials, mainly limestones and dolomites, by Zakłady Dolomitowe Szczakowa and abandoned open pits after exploitation of sand, which led to considerable liquidation of soil layers, formation of sinks and unorganised waste disposal sites. Moreover, the formations of rocky substrate in that area exhibit weak insulation properties due to their natural porosity, karst formation and many faults [2]. Apart from adverse natural conditions, human impact effects are also visible: they result in depressurisation of orogenic belt with mining drainage. Exploitation activity is also connected with dewatering of mines, which results in depression funnels, which cover extensive urban areas in the case of the city of Jaworzno. What is also important is the inflow of underground waters after the exploitation ends and change in hydrological conditions in the areas of the funnels [9]. Inflowing mine waters have a characteristic, high mineralisation level, are characterised by high salinity, sulphate content and general hardness. Frequently, the effect of mine waters on underground resources makes it impossible to collect water for potting purposes, e.g. due to too high chloride concentration, as in the case in another underground water intake (WTP J. Dąbrowski) in Jaworzno.

Despite close proximity, waters taken from wells D-1 and D-2 have different qualitative content. In general, the quality of waters taken from well D-1 is better compared to well D-2, apart from winter and spring time, when colour in the water taken in by well D1 increases to values not accepted by the consumer. The water in D-2 well is characterised by periodically high contents of boron and lead. Parameters influencing decrease in the quality of the waters taken from well D-2 are also $\mathrm{Cr}^{6+}$ ions and sulphates $\left(\mathrm{SO}_{4}{ }^{2-}\right)$ and their presence must be linked with the neighbourhood of municipal waste disposal site located in a closed quarry remaining after dolomite exploitation. This facility has had a considerable adverse effect on the quality of underground waters in the area of the Dobra intake.

\section{Selected parameters characterising the quality of underground water from the area of the disposal site and the intake}

Undoubtedly, what has had an influence on contamination of the environment in the area of supply of the Dobra intake has been the storage of municipal waste in the excavation site of former dolomite mine since 1971 . The quality of that waste and the manner of their storage, as well as the very use of the disposal site have influenced the quality of soils and waters in that region. What caused serious threat to the environment were mainly activities connected with illegal storage of dangerous waste from the local tannery in the past. At the turn of 2002/2003, the influence of drains from the disposal site on the waters of the Dobra intake for content of chromium probably from tannery waste was analysed [10]. Attention was paid to the tannery waste deposited in the area of the disposal site in the 1990s, which waste contained a considerable concentration of chromium, which led to contamination of the vadose zone under the municipal waste disposal site and penetration of chromium to underground waters in the area of the Dobra intake. Chromium concentrations (Fig. 1 and Fig. 2) in the examined water samples varied from amounts characteristic of the geochemical background $(<$ $0.005 \mathrm{mg} / \mathrm{L})$ to concentrations of ca. $0.04 \mathrm{mg} / \mathrm{L}$. The contents of that element exceeding $0.01 \mathrm{mg} / \mathrm{L}$ constantly occurred in piezometer P-II and in well D-2 of the Dobra intake in years 2000-2002. Analyses of dynamics of water chromium content illustrated in Fig. 1 show that in piezometer P-II water, the average annual chromium content decreased by $31 \%$ over 30 months to the level of $0.012 \mathrm{mg} / \mathrm{L}$ (September and October 2002).

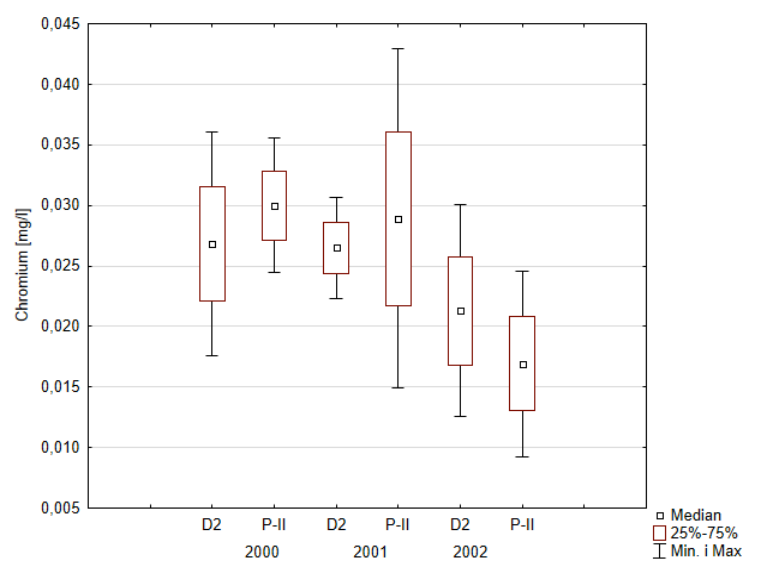

Fig. 1. Chromium contents in water samples taken from the piezometer P-II and the well D-2 in 2000-2002.

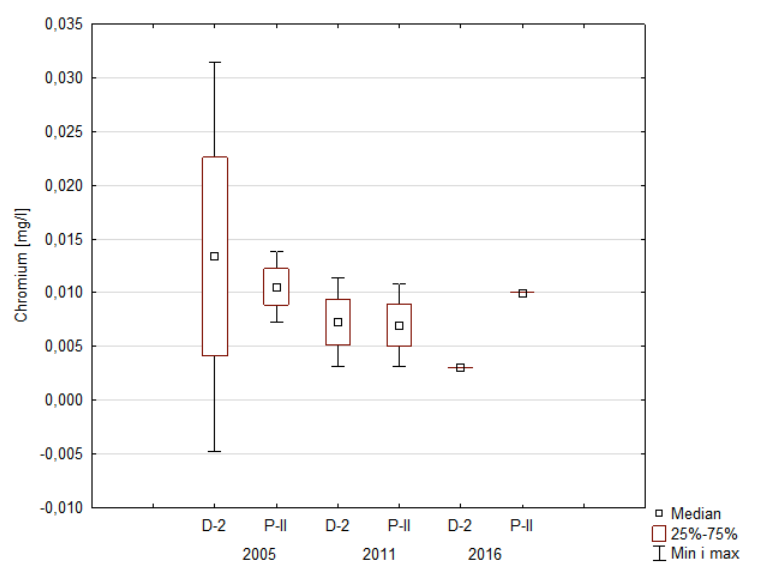

Fig. 2. Chromium contents in water samples taken from the piezometer P-II and the well D-2 in 2005, 2011 and 2016.

A decreasing trend in chromium content was also observed in well D-2 of the Dobra water intake, which from $0.035 \mathrm{mg} / 1$ measured in 2000 dropped to 0.015 $\mathrm{mg} / \mathrm{L}$. What was also observed was a correlation between seasonal changes in underground water table and chromium content in the examined water samples. The observed decrease in underground water table is related to lower chromium contents and - analogously the rebuilding of underground water table is correlated with higher chromium contents. The observed 
phenomenon can be associated with more or less intense flushing of strongly contaminated vadose zone located directly under the disposal site, which results from high fluctuations in the ordinate of underground water table in that region [10]. The fact that the disposal site has an effect on the intake is confirmed by the results of monitoring of underground waters performed in the area of the disposal site later on.

Studies conducted in following years 2005-2016 showed that from 2010 there had been a considerable decrease in chromium content in underground waters of the Dobra intake both in piezometers and the D-2 well.

\subsection{Microbiology}

Over the 9 first years of use of the disposal site, liquid impurities, i.e. municipal sewage, were poured over the deposited waste periodically. Until 1978, the waters taken from the Dobra intake were compliant with the microbiological quality requirements for potable waters. In mid-1979, faces-type bacteria contamination occurred in the underground waters of the intake in question and in December of that year considerable bacteriological contamination took place [11]. Therefore, a sanitary inspectorate prohibited pouring sewage on the disposal site and ordered chlorination of the water from the Dobra WTP before supplying it to the consumers. Physicochemical analyses from the period of 14 years of use (1978-1991) showed that the highest contamination of the waters was observed in years 1986-87, when water level in the well was decreasing. A hydrogeological expert opinion prepared by the Expert Team of the Society of Mining Engineers and Technicians showed that the phenomenon in question was caused by dewatering of dolomite deposits by the Gródek mine, the wells of which drain the same water-bearing level of the Triassic. In the 1990s, during intensifying disappearance of water in the well of the Dobra intake, a decision was made to feed the well with waters from the dolomite mine dewatering barrier. Three wells and pumping systems directed the water from the local excavation to the well of the Dobra intake [11]. At that time, the microbiological quality of water was characterised by $400 \mathrm{CFU} / \mathrm{mL}$ of Coli group bacteria. The taken action decreased the problem of microbiological water contamination in the Dobra intake to $95 \%$. Since 1992, laboratory analyses of underground water quality have shown single, incidental occurrences of Coli group bacteria and the overall number of microorganisms both in piezometers and wells D1 and D2.

\subsection{Boron}

Out of all microelements, boron (B) is the potential, characteristic contaminant for drains from municipal waste disposal sites. To remove it from water, it is necessary to apply some special methods like ion exchange or reverse osmosis. In the case of small, local potable water intakes, treatment with energy-draining and cost-draining methods becomes unprofitable, which
- in the case of persistent excess of boron content in potable waters - puts an intake in danger of closing.

Persistent boron content in underground waters (Table 1) in studies covering the period from 2012 to 2016 confirm the hydraulic connection of the intake, mainly well D2, with waters from the drainage zone from the disposal site. Periodically, the water taken in well D2 does not meet the requirements of the Regulation of the Minister of Health $(\mathrm{RMH})$ on quality of water intended for consumption by people. To meet the legal requirements for the quality of waters intended for consumption by people, the Dobra WTP uses mixing of streams of waters from well D1 and D2 in a proper ratio, which guarantees that boron content remains at a level lower than $1 \mathrm{mg} / \mathrm{L}$.

Table 1. Boron contents in water samples taken from the piezometer P-I, P- II, P-III and the well D-1 and D- 2.

\begin{tabular}{|c|c|c|c|c|c|c|}
\hline \multirow{2}{*}{ Date } & \multicolumn{6}{|c|}{ Boron (mg/L) in 2012-2016 } \\
\cline { 2 - 7 } & \multicolumn{2}{|c|}{ Well D1 } & \multicolumn{2}{c|}{ Well D2 } & \multicolumn{2}{c|}{ Piezometers } \\
\cline { 2 - 7 } & Norm & Result & Norm & Result & Norm & Result \\
\hline $\mathbf{2 0 1 2}$ & 1 & NDA $^{*}$ & 1 & NDA $^{*}$ & 1 & 0.108 \\
\hline $\mathbf{2 0 1 3}$ & 1 & 0.27 & 1 & 1.39 & 1 & 0.19 \\
\hline $\mathbf{2 0 1 4}$ & 1 & 0.196 & 1 & 1.55 & 1 & 0.58 \\
\hline $\mathbf{2 0 1 5}$ & 1 & 0.19 & 1 & 1.50 & 1 & 0.11 \\
\hline $\mathbf{2 0 1 6}$ & 1 & 0.24 & 1 & 0.96 & 1 & NDA $^{*}$ \\
\hline
\end{tabular}

*NDA- Not data avaliabe

\subsection{Sulphates}

The data illustrated in Table 2 show high sulphate content in underground water. The origin of sulphates in Triassic underground waters is difficult to pinpoint as they are polygenetic, can stem both from external and internal sources of contamination. The sources of external contamination are all types of solid waste disposal sites and liquid waste disposal sites, which are present in the area of the intake. On the other hand, the internal foci are products of natural geochemical processes occurring in the orogenic belt, but initiated by human activity [11-13].

Table 2. Sulphates contents in water samples taken from the piezometer P-I, P- II, P-III and the well D-1 and D- 2.

\begin{tabular}{|c|c|c|c|}
\hline \multirow{2}{*}{ Date } & \multicolumn{3}{|c|}{ Sulphates (mg/L) in 2004-2016 } \\
\cline { 2 - 4 } & Well D1 & Well D2 & Piezometrs \\
\hline $\mathbf{2 0 0 4}$ & 100.8 & 191.4 & 0.0 \\
\hline $\mathbf{2 0 0 5}$ & 99.7 & 180.3 & 106.7 \\
\hline $\mathbf{2 0 0 6}$ & 97.8 & 188.6 & 99.7 \\
\hline $\mathbf{2 0 0 7}$ & 89.4 & 199.1 & 100.0 \\
\hline $\mathbf{2 0 0 8}$ & 89.2 & 202.4 & 106.3 \\
\hline $\mathbf{2 0 0 9}$ & 101.0 & 225.6 & 0.0 \\
\hline $\mathbf{2 0 1 0}$ & 119.8 & 245.6 & 93.0 \\
\hline $\mathbf{2 0 1 1}$ & 84.0 & 184.0 & 78.9 \\
\hline $\mathbf{2 0 1 2}$ & 83.3 & 193.3 & 127.3 \\
\hline $\mathbf{2 0 1 3}$ & 97.8 & 167.4 & 87.5 \\
\hline $\mathbf{2 0 1 4}$ & 98.3 & 201.0 & 124.7 \\
\hline $\mathbf{2 0 1 5}$ & 93.1 & 177.2 & 101.4 \\
\hline $\mathbf{2 0 1 6}$ & 104.4 & 187.3 & 0.0 \\
\hline
\end{tabular}

The Table 2 also shows differentiation in the quality of 
waters taken from wells D1 and D2 despite their close proximity. Not only sulphates, but also parameters such as overall hardness, conductivity, boron, chromium and colour confirm considerable diversification in the content of those waters.

\subsection{Colour}

The above graph shows a diversification in waters taken from wells D1 and D2. The conducted analysis showed that in the 1st and 4th quarter there is the highest increase in colour of water taken from well D1 (maximum colour of $25 \mathrm{mg} \mathrm{Pt} / \mathrm{L}$ on 17-03-2016), which is caused by thawing and long-term precipitation resulting in an abrupt increase in the water level in the local stream. Increase in colour during autumn, winter and spring time repeats year after year, which is illustrated in the above graph (Fig. 3 and 4). The conducted analysis showed that the most probable cause of abrupt increase in the colour, frequently above admissible values, shows that there is no insulation of the water-bearing layers in well D1. At the same time, infiltration was noted of underground waters from the Łużnik stream found nearby, which stream runs 5 metres away from well D1.

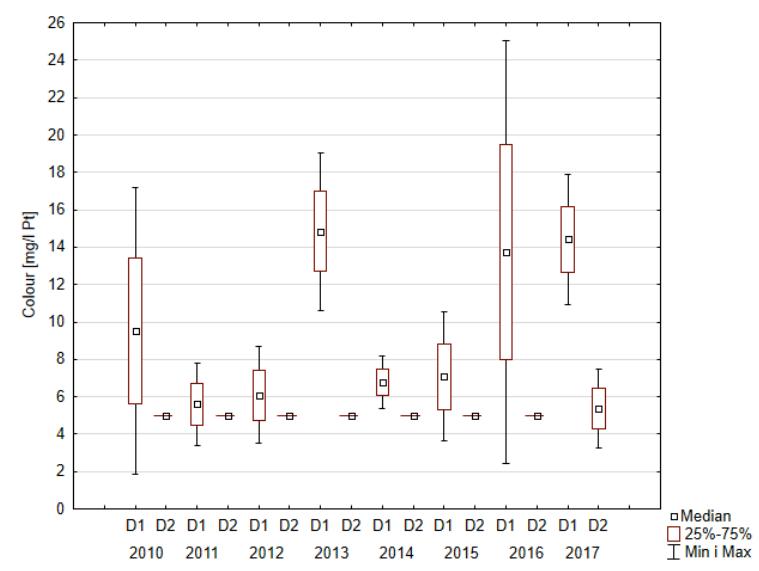

Fig. 3. Colour of water samples taken from the piezometer P-I, P- II, P-III and the well D-1 and D- 2 in 2010-2017 (I Quarter).

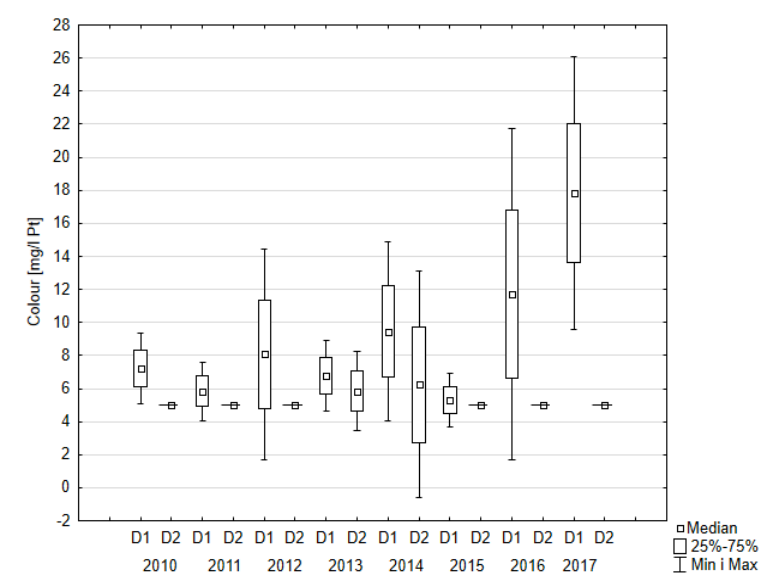

Fig. 4. Colour of water samples taken from the piezometer P-I, P- II, P-III and the well D-1 and D- 2 in 2010-2017 ( IV Quarter).

\section{Conclusions}

Quality of underground waters in Triassic carbonate formations is monitored by three piezometers surrounding the closed waste disposal site and the Gródek quarry and two deep wells located in the area of the Dobra intake. The analysed parameters show a decrease trend in chromium content in water from the Dobra intake. Microbiological contamination of water has also stabilised compared to the 1990s.

What is currently a use-related problem of the Dobra intake is periodical failure to meet the requirements imposed by the Regulation of the Minister of Health of 07 December 2017 on the quality of water intended for consumption by people (Journal of Laws of 2017, item 1989), concerning intensified colour and boron.

Due to hydraulic connection of the underground water resources of the Dobra intake with the Gródek tank, there is high likelihood that the intake waters will be contaminated with impurities deposited at the bottom, formed in the process of flooding. For many years, at the bottom of the quarry there were two excavators, which could not be removed before cutting the power supply, and vehicles and an airplane flooded on purpose, to improve the appeal of the area as a scuba diving site. The former quarry is developing dynamically as a recreation and scuba-diving site, being the key threat of deterioration of the quality of underground waters intended for consumption by Jaworzno inhabitants.

At present, reclamation work is performed in the closed waste disposal site. In addition, constant, detailed monitoring of drains from the closed waste disposal site has been introduced. It aims to determine the level of threat for the quality of underground water resources of the Dobra intake and to develop and verify preventive actions for protection of those resources in accordance with the principles of water supply risk management.

\section{Reference}

1. J. Wiater, JEE 26, (2011)

2. M. Działoszyńska-Wawrzkiewicz, K. MoraczewskaMajkut, K. E. Szymura, W. Nocon, Ochr. Sr. 37, 2 (2015)

3. M. Gono, M. Kyncl, R. Gono, I. Klosok-Bazan, PE 11, 89 (2013)

4. J. Boguniewicz-Zablocka, I. Klosok-Bazan, V. Naddeo, Environ. Sci. Pollut. Res. (2017) (doi: 10.1007/s11356-017-0608-8)

5. M. Wolska, Water Sci. Technol. 71, 4 (2015)

6. M. Bożym, I. Kłosok-Bazan, M. Wzorek, Pol. J. Environ. Stud. 27, 3 (2018)

7. M. Wolska, Desalin. Water Treat. 52, (2014)

8. B. Gajowiec, Projekt badań hydrogeologicznych dla ujęcia ,Dobra” w Jaworznie, (Sosnowiec, 1998)

9. J. Pleczyński, JEE 7/8, (1999)

10. Bauerek, M. Gwoździewicz, Migracja chromu $w$ wodach podziemnych weglanowej serii triasu rejonu ujęcia „Dobra” w Jaworznie, (Główny Instytut Górnictwa, 2003)

11. M. Bacewicz, Biuro Projektów Bud. Komun.w 
Krakowie: Dokumentacja - Ujęcie wód dolomitowych Dobra (1993)

12. J. Motyka, Z. Adamczyk, M. Czop, K. Dobyrn, Gosp. Sur. Min. 21, 1 (2005)

13. M. Goździewicz, Dodatek do dokumentacji hydrogeologicznej ustalajacej zasoby eksploatacyjne wód ujęcia Dobra, (2013)

14. C.B. Öman, C. Junestedt, Waste Manage. 10, (2008) 